Ann. Génét. Sél. anim., I979, 11 (I), I45-I59.

\title{
Phenotypic and genetic relationships between endocrine cri- teria and testicular measurements of young Romanov rams and the ovulation rates at 8 months of their half-sisters
}

\author{
G. RICORDEAU $(*)$, J. PELLETIER, M. COUROT and J. THIMONIER \\ with the technical assistance of: \\ F. Eychenne $(*)$, R. Mollaret $(*)$, R. Duzert $(*)$, D. Lajous $(*)$ and A. Caraty
}

(*) Station d'Amélioration Génétique des Animaux, Centre de Recherches de Toulouse, I.N.R.A.

B.P. I2, 31320 Castanet Tolosan

Station de Physiologie de la Reproduction,

Centre de Recherches de Tours, I.N.R.A., 37380 Nouzilly

\section{Summary}

The object of this study was to estimate the relationships between levels of plasma L.H of male Romanov lambs at 4,6 and 8 weeks, their testicular growth and the ovulation rate of their paternal half-sisters. Sixty-eight lambs were involved in 1976 and 74 in 1977 from a total of $r_{4}$ sires. At each age, 3 samples of blood were taken and the terticular diameter was measured at 42,70 and roo days in 1976 , and at 70 , Ioo and 140 days in 1977 .

The mean level of L.H. was a maximum at 6 weeks of age and the correlation between mean L.H. levels at 6 and 8 weeks was highly significant. Differences between progeny of sires for mean L.H. levels (calculated from the 3 ages together) and testicular growth between 70 and roo days (corrected for liveweight) were only highly significant in 1977.

All correlations between L.H. levels and testicular measurements were non-significant. The mean ovulation rates of each sire's ewe lambs were independent of the mean L.H. level of their half-brothers, although there was a positive but non-significant correlation with the testicular growth from 70 to 100 days of their half-brothers $(0.43 ; n=14)$.

The high pulse frequency of LH levels of lambs at this age did nct interfere with the results obtained as was shown by a complementary study of $\mathrm{r}_{4}$ lambs from which blood samples were. taken at 20 minute intervals for 6 hours at both 6 and 8 weeks of age.

\section{Introduction}

The gonadotropic hormones L. H. and F.S.H. $\left({ }^{*}\right)$ can be measured at birth in the blood plasma of both male and female lambs. The observations of THIMONIER, PELLETIER and LAND (I972), then those of BLANC et al. (I975) indicated

(*) Luteinizing hormone and Follicle-stimulating hormone. 
that between 4 and II weeks, the level and variation of plasma L.H. concentration of lambs depends on the genetic type and is related to ovulation rates among females of the same type. CARR and LAND (I975) observed a comparable result with young males from 7 to I3 weeks, but ECHTERNKAMP and LASTER (I976), HANRAhan et al. (I977) and WesthuYSEn and DiERKSE (I977) did not observe the correlation. In the same breed, BINDON (1973) showed that at 30 days, male and female lambs from groups selected for high fertility had higher levels of plasma L.H. than lambs from groups selected for low fertility. BINDON also presented evidence of significant differences in plasma $\mathrm{L}_{\mathrm{H}} \mathrm{H}$ levels between families and between type of birth classes. Trounson et al. (1974) confirmed this result in comparing measurements made at 5 months among males from groups selected for either high or low fertility. However, BINDON and PIPER (I976) noted that in their $\mathrm{O}, \mathrm{T}$ and $\mathrm{B}$ Merino flocks, there was no correlation between the concentration of $\mathrm{LH}$ of female lambs at $3^{\circ}$ days of age and subsequent litter size, irrespective of whether $\mathrm{L}_{\mathrm{H}} \mathrm{H}$ was determined from a single sample or a series. In other experiments, LAND (I972, I973 and I977), LAND and CARR (I975) showed that testicular growth was more rapid in genetically highly fertile types and that selection of Finn-Dorset sheep for or against testicular growth caused differences in fertility and fecundity of ewes at I year of age.

This study aimed to verify these results within a highly fertile breed, by comparing plasma L.H. levels and testicular growth of young Romanov rams with the first reproductive performance of their paternal half-sisters.

\section{Materials and methods}

This study was made using male and female lambs which were the progeny of I4 Romanov rams following the protocol outlined in table $\mathrm{I}$.

TABLE I

Animal numbers and measurements made on lambs of both sexes

Matériel animal et mesures réalisées sur les agneaux des 2 sexes

\begin{tabular}{|c|c|c|c|c|}
\hline \multirow[b]{3}{*}{$\begin{array}{l}\text { Period } \\
\text { of birth }\end{array}$} & \multicolumn{2}{|c|}{ Ist series: 7 families or progeny } & \multicolumn{2}{|c|}{ 2nd series: 7 families } \\
\hline & males & females & males & females \\
\hline & Jan.-feb. 1976 & $\begin{array}{l}\text { Jan.-feb. } 1975 \\
\text { Jan.-feb. } 1976\end{array}$ & Jan.-feb. 1977 & Jan.-feb. 1977 \\
\hline $\begin{array}{l}\text { Measure } \\
\text { of L.H. } \\
\text { Diameter of } \\
\text { testicles } \\
\text { Ovulation } \\
\text { rate.. }\end{array}$ & $\left\{\begin{array}{l}\text { 4-6-8 weeks }(68) \ldots \\
42-70-100 \text { days }(66)\end{array}\right.$ & $\begin{array}{lll}\text { Nov. } & \text { I975 } & (79) \\
\text { Nov. } & 1976 & (88)\end{array}$ & $\left\{\begin{array}{l}\text { 4-6-8 weeks }(74) \\
70-100-140 \text { days }(96)\end{array}\right.$ & Nov. 1977 (79) \\
\hline
\end{tabular}

( ) = Numbers of lambs.

Measurements of right testicular diameter were not taken by the same person in 1976 and 1977. 


\section{I. - Measurements}

All lambs were weighed at birth (January-february), then each 3 weeks. Age-adjusted weights were calculated by linear interpolation for standard ages of 40,70 , Ioo and I 40 days.

Two sets of measurements were made on the male lambs:

a) Blood samples were taken at 4,6 and 8 weeks ( \pm 3 days). At each age, 3 samples were collected at intervals of I hour starting at $8.30 \mathrm{am}$. Immediately after collection, the samples were stored in ice. They were centrifuged and the plasma drawn off approximately I hour after collection. The plasma samples were stored at $-\mathrm{I} 2{ }^{\circ} \mathrm{C}$ until their $\mathrm{LH}$ concentration was measured by the radioimmunoassay described by PELLETIER et al. (I968). The results are given in $\mathrm{ng} / \mathrm{ml}$ of plasma: solution $\mathrm{LH}_{\mathrm{H}} \mathrm{M}_{3}=\mathrm{I} .8 \mathrm{LH}-\mathrm{NIH}-\mathrm{Sr}$. The samples from each annual series (I976 and I977) were measured in one assay, but with one year between collections which could explain the difference in L.H. level from one series to the other.

b) Measurement of the diameter of the right testicle (including the thickness of scrotal skin) was made with a set of callipers at 42,70 and roo days in 1976 and 70 , roo and I40 days in $1977\left(^{*}\right)$.

Average litter sizes were 2.9 for the 68 lambs born in 1976 ( 16 p. roo twins, 69 p. Ioo triplets and $\mathrm{r} 3 \mathrm{p}$. Ioo quadruplets) and 3.2 for the 93 lambs born in 1977 ( 8 p. roo twins, 54 p. roo triplets and 34 p. roo quadruplets).

Ewe lambs belonging to the same families as these males were observed at 9 months of age. Their ovulation rates were estimated from the number of corpora lutea observed using an endoscope as described by THIMONIER and MAULÉON (rg69).

\section{2. - Statistical analysis}

As measures of L.H. concentrations had an asymetric distribution, a squareroot transformation was used for analysis. In order to estimate basal L.H. level, excluding peaks, an "L.H. minimum " value was taken to be the lowest of the 3 hourly measures of L.H. at each age. Statistical tests, correlations and analysis of variance were calculated only on the transformed measurements. Repeatability was calculated from the intraclass correlation $(\rho)$ after analysis of variance, and from the mean of correlation coefficients between the observed measurements $(r)$.

In order to eliminate the influence of live weight on measures of testicular diameter, age-adjusted diameters were corrected using the linear regression of diameter on weight calculated for each standard age. This allowed the calculation of corrected testicular diameter (C. TD) and corrected testicular growth (C. TG).

On account of the differences in L.H. levels and variances in 1976 and I977, correlations and analysis of variance have been calculated separately for each year. Mean correlations were then calculated after $Z$ transformations of the separate correlations. In view of the small numbers of progeny, we have not estimated heritabilities or genetic correlations from the half-sibs progeny groups. study.

(*) Two males in 1976 and another 2 in 1977 which had uneven testicles were eliminated from the 


\section{Results}

\section{I. - Observations on young males}

\section{LH levels}

a) On the whole, the effect of age was highly significant. The level of LH was a maximum at 6 weeks and was significantly different to that observed at 4 weeks in both 1976 and I977. There were no significant differences between $\mathrm{LH}$ levels at 6 and 8 weeks, except for a difference between mean $\sqrt{\mathrm{LH}}$ minimum levels in 1977 (Table 2a).

TABLE 2

Mean performances and variabilities

Performances moyennes et variabilité

a) Measurements of L.H.

Mesures de $L H$

\begin{tabular}{|c|c|c|c|c|c|c|c|c|}
\hline \multirow[t]{2}{*}{ Year } & Age & \multicolumn{2}{|c|}{4 weeks } & \multicolumn{2}{|c|}{6 weeks } & \multicolumn{2}{|c|}{8 weeks } & \multirow{2}{*}{$\begin{array}{c}\begin{array}{c}4 \text { to } \\
8\end{array} \\
\text { weeks }\end{array}$} \\
\hline & Variable & $\bar{x}$ & $\sigma / \sqrt{n}$ & $\bar{x}$ & $\sigma / \sqrt{n}$ & $\bar{x}$ & $\sigma / \sqrt{n}$ & \\
\hline 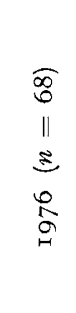 & 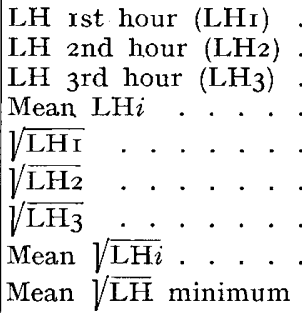 & $\begin{array}{c}3, \mathrm{I} 4 \\
3,7 \mathrm{I} \\
5,99 \\
4,28 \\
\mathrm{I}, 63 \\
\mathrm{I}, 72 \\
2,07 \\
\mathrm{I}, 8 \mathrm{I}(a) \\
\mathrm{I}, 27(a)\end{array}$ & $\begin{array}{l}0,08 \\
0,10 \\
0,16 \\
0,08 \\
0,05\end{array}$ & $\begin{array}{l}4,73 \\
5,33 \\
5,7 \mathrm{I} \\
5,26 \\
2, \mathrm{O} 6 \\
2, \mathrm{I} 2 \\
2, \mathrm{I} 9 \\
2, \mathrm{I} 2(b) \\
\mathrm{I}, 6 \mathrm{I} \quad(b)\end{array}$ & $\begin{array}{l}0,08 \\
0, I I \\
0, I I \\
0,08 \\
0,07\end{array}$ & $\begin{array}{r}3,95 \\
4,36 \\
4,04 \\
4, \mathrm{I} \\
\mathrm{I}, 89 \\
\mathrm{I}, 93 \\
\mathrm{I}, 85 \\
\mathrm{I}, 89(a, b) \\
\mathrm{I}, 50(b)\end{array}$ & $\begin{array}{l}0,08 \\
0,10 \\
0,09 \\
0,07 \\
0,06\end{array}$ & $\begin{array}{l}3,94 \\
4,47 \\
5,25 \\
4,55\end{array}$ \\
\hline 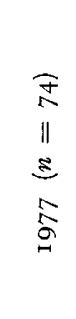 & 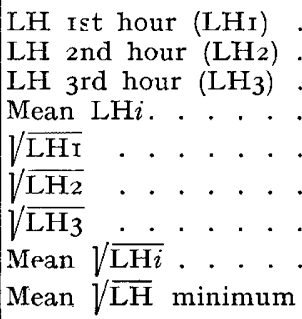 & $\begin{array}{l}\mathrm{I}, 92 \\
2,3 \mathrm{I} \\
\mathrm{I}, 9 \mathrm{I} \\
2,05 \\
\mathrm{I}, 30 \\
\mathrm{I}, 39 \\
\mathrm{I}, 27 \\
\mathrm{I}, 32(a) \\
\mathrm{I}, 00(a)\end{array}$ & $\begin{array}{l}0,06 \\
0,07 \\
0,06 \\
0,04 \\
0,04\end{array}$ & $\begin{array}{c}2,73 \\
2,97 \\
2,72 \\
2,8 \mathrm{I} \\
\mathrm{I}, 59 \\
\mathrm{I}, 63 \\
\mathrm{I}, 52 \\
\mathrm{I}, 5^{8}(b) \\
\mathrm{I}, 22(b)\end{array}$ & $\begin{array}{l}0,05 \\
0,06 \\
0,07 \\
0,05 \\
0,04\end{array}$ & $\begin{array}{r}2,56 \\
2,2 \mathrm{I} \\
2,35 \\
2,38 \\
\mathrm{I}, 54 \\
\mathrm{I}, 39 \\
\mathrm{I}, 38 \\
\mathrm{I}, 44(a, b) \\
\mathrm{I}, 05(a, c)\end{array}$ & $\begin{array}{l}0,05 \\
0,06 \\
0,08 \\
0,05 \\
0,04\end{array}$ & $\begin{array}{l}2,4 \mathrm{I} \\
2,50 \\
2,33 \\
2,4 \mathrm{I}\end{array}$ \\
\hline
\end{tabular}
level.

On the same line, means followed by the same letter are not significantly different at the $5 \mathrm{p}$. roo 


\section{TABIE 2 (continued)}

b) Testicular measurements $(\mathrm{cm})$ and liveweight $(\mathrm{kg})$

Mesures testiculaires $(\mathrm{cm})$ et poids vif $(\mathrm{kg})$

Diameter of testicles at 42 days ........

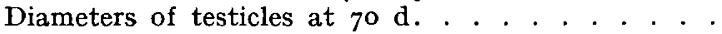

Diameter of testicles at Ioo d. . . . . . . . .

\begin{tabular}{|c|c|c|c|}
\hline \multicolumn{2}{|c|}{$1976(n=66)$} & \multicolumn{2}{|c|}{ I977 $(n=93)$} \\
\hline $\bar{x}$ & $\sigma / \sqrt{n}$ & $\bar{x}$ & $\sigma / \sqrt{n}$ \\
\hline 1,74 & 0,03 & 一 & - \\
\hline 3,22 & 0,07 & 2,90 & 0,03 \\
\hline 4,27 & 0,06 & $4, \mathrm{I} 5$ & 0,04 \\
\hline 一 & - & 5,12 & 0,05 \\
\hline 2,54 & 0,06 & $\longrightarrow$ & - \\
\hline 1,06 & 0,06 & 1,25 & 0,06 \\
\hline 一 & 一 & 2,23 & 0,05 \\
\hline 11,00 & 0,23 & 一 & - \\
\hline 19,69 & 0,35 & $20,5^{6}$ & 0,23 \\
\hline 28,38 & $0,5 \mathrm{I}$ & $28,7^{\circ}$ & 0,31 \\
\hline 一 & 一 & 39,00 & $0,5 \mathrm{I}$ \\
\hline 2,9 & & 3,2 & \\
\hline
\end{tabular}

Growth 42-100 d. . . . . . . . . . . . .

Growth 70-100 d. . . . . . . . . . . . . . . .

Growth 70-I $40 \mathrm{~d}$.

Liveweight at $42 \mathrm{~d}$

Liveweight at $70 \mathrm{~d}$.

Liveweight at roo d . . . . . . . . . .

Liveweight at $\mathrm{I}_{4} \mathrm{O} \mathrm{d} . \ldots . . . . .$.

Litter size or type of birth . . . . . . . .

$\overrightarrow{2,9}$

TABLE 3

Repeatabilites of L.H. level and of testicular diameter

Répétabilités du niveau de L.H. et du diamètre testiculaire

a) Components of variance. Intraclass correlation of hourly measurements of $\sqrt{L H}$ at the three ages (repeatability between hours)

Composante de la variance. Coefficients de corrélation intraclasse des mesures horaires de $\sqrt{L H}$ aux 3 ages (répétabilité entre mesures horaires)

\begin{tabular}{|c|c|c|c|c|c|c|c|c|c|}
\hline \multirow{2}{*}{$\begin{array}{c}\text { Variance } \\
\text { components }\end{array}$} & \multicolumn{4}{|c|}{$1976(n=68)$} & \multicolumn{4}{|c|}{ I977 $(n=74)$} & \multirow{2}{*}{$\begin{array}{c}\text { Ratio } \\
\text { var. 1976 } \\
\text { var. 1977 }\end{array}$} \\
\hline & $4 \mathrm{w}$ & $6 \mathrm{w}$ & $8 \mathrm{w}$ & $\bar{x}$ & $4 \mathrm{w}$ & $6 \mathrm{w}$ & $8 \mathrm{w}$ & $\bar{x}$ & \\
\hline 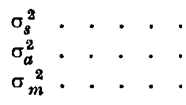 & $\begin{array}{l}0,0182 \\
0,274 \mathrm{I} \\
0,7369\end{array}$ & $\begin{array}{l}0,0754 \\
0,1602 \\
0,5368\end{array}$ & $\begin{array}{l}0,0078 \\
0,2432 \\
0,2996\end{array}$ & $\begin{array}{l}0,0338 \\
0,2258 \\
0,5245\end{array}$ & $\begin{array}{l}0,0185 \\
0,0428 \\
0,2490\end{array}$ & $\begin{array}{l}0,0029 \\
0,0693 \\
0,2456\end{array}$ & $\begin{array}{l}0,0478 \\
0,0493 \\
0,2268\end{array}$ & $\begin{array}{l}0,0230 \\
0,053^{8} \\
0,2401\end{array}$ & $\begin{array}{l}1,5 \\
4,2 \\
2,2\end{array}$ \\
\hline$\cdot \cdot \cdot$ & 0.28 & 0,30 & 0,45 & 0.33 & 0,19 & 0.23 & 0.30 & 0.24 & \\
\hline
\end{tabular}

$\sigma_{s}^{2}=$ sire variance.

$\sigma_{a}^{2}=$ animal variance (ram lamb).

$\sigma_{m}^{2}=$ measurement variance.

$\left(^{*}\right)$ ratio between the variances observed in 1976 and 1977 .

$\rho=$ intraclass correlation between measurements $=\left(\sigma_{s}^{2}+\sigma_{a}^{2}\right) /\left(\sigma_{s}^{2}+\sigma_{a}^{2}+\sigma_{m}^{2}\right)$. 


\section{TABLE 3 (suite)}

b) Correlation coefficients between ages for mean $\sqrt{\overline{L H}}$ and $\sqrt{\overline{L H}}$ minimum (repeatability between ages) Coefficients de corrélation entre ages pour les variables moyenne $\sqrt{\overline{L H}}$ et $\sqrt{\mathrm{LH}}$ minimum (vépétabilité entre ages)

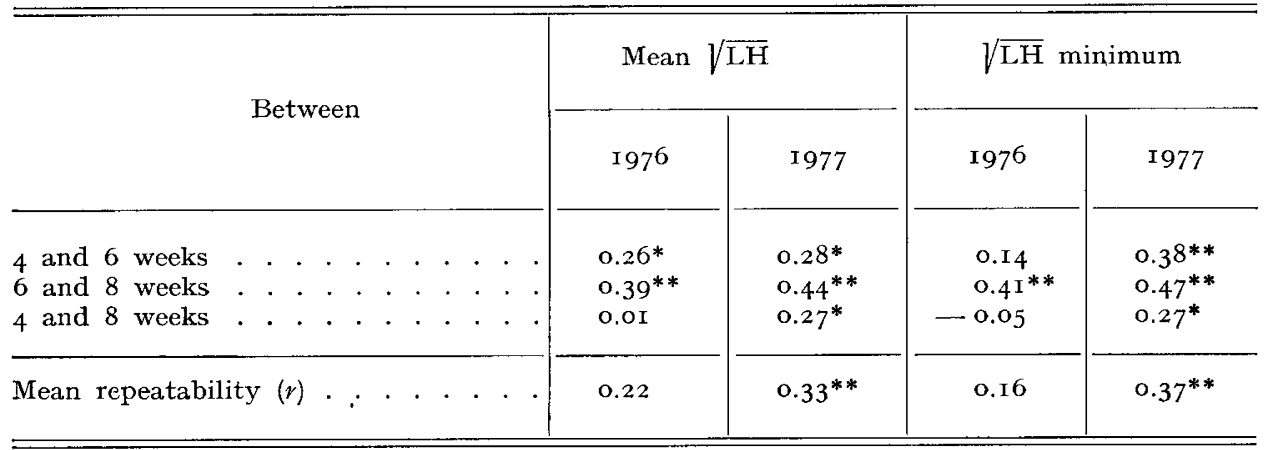

c) Testicular diameter corrected for liveweight: repeatability between ages ( $v)$

Diamètre testiculaire corrigé pour le poids vif: répétabilité entre ages

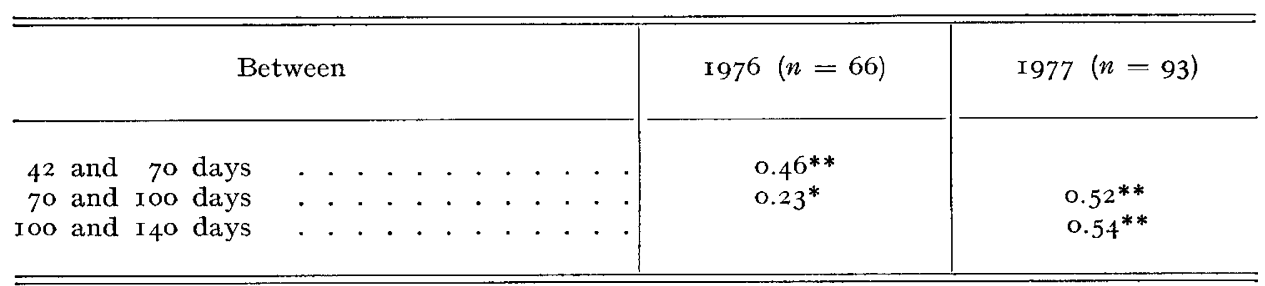

b) At each age, the hourly measurements of $\sqrt{\mathrm{LH}}$ were not significantly different (Table $2 a$ ). The repeatability (intraclass correlation) was 0.33 in 1976 and 0.24 in 1977 (Table $3 a$ ). This variation resulted from the differences in components of variance between the two years: thus, the between-animal variance is 4.2 times higher in 1976 than in 1977 , while the between-sire variance and the between-measurements variance were only 1.5 and 2.2 times higher in 1976 than in I977, respectively.

c) The correlation between mean L.H levels (calculated from the 3 samplings) at 6 and 8 weeks was highly significant (Table $3 b$ ). However, the correlations between mean LH measured at 4 and 6 weeks or at 4 and 8 weeks were close to zero or just significant. The repeatabilities of mean $\sqrt{\mathrm{LH}}$ and $\sqrt{\mathrm{LH}}$ minimum were only significant in 1977 .

In both I976 and I977 the various measures of L.H. level at the 3 ages had positive but non-significant correlations $(r<0.20)$ with liveweight at 42 days, therefore no corrections have been made to these variables.

\section{Testicular growth}

Taking the two years together, testicular diameters were: $1.7,3.0,4.2$ and $5.1 \mathrm{~cm}$ at 42,70 , Ioo and 140 days respectively (Table 2 , fig. I). The repeatabilities of testicular diameter at 30 or 40 day intervals were relatively low (0.23 to 0.54 ), the best being in 1977 with the second operator (Table $3 c$ ). 

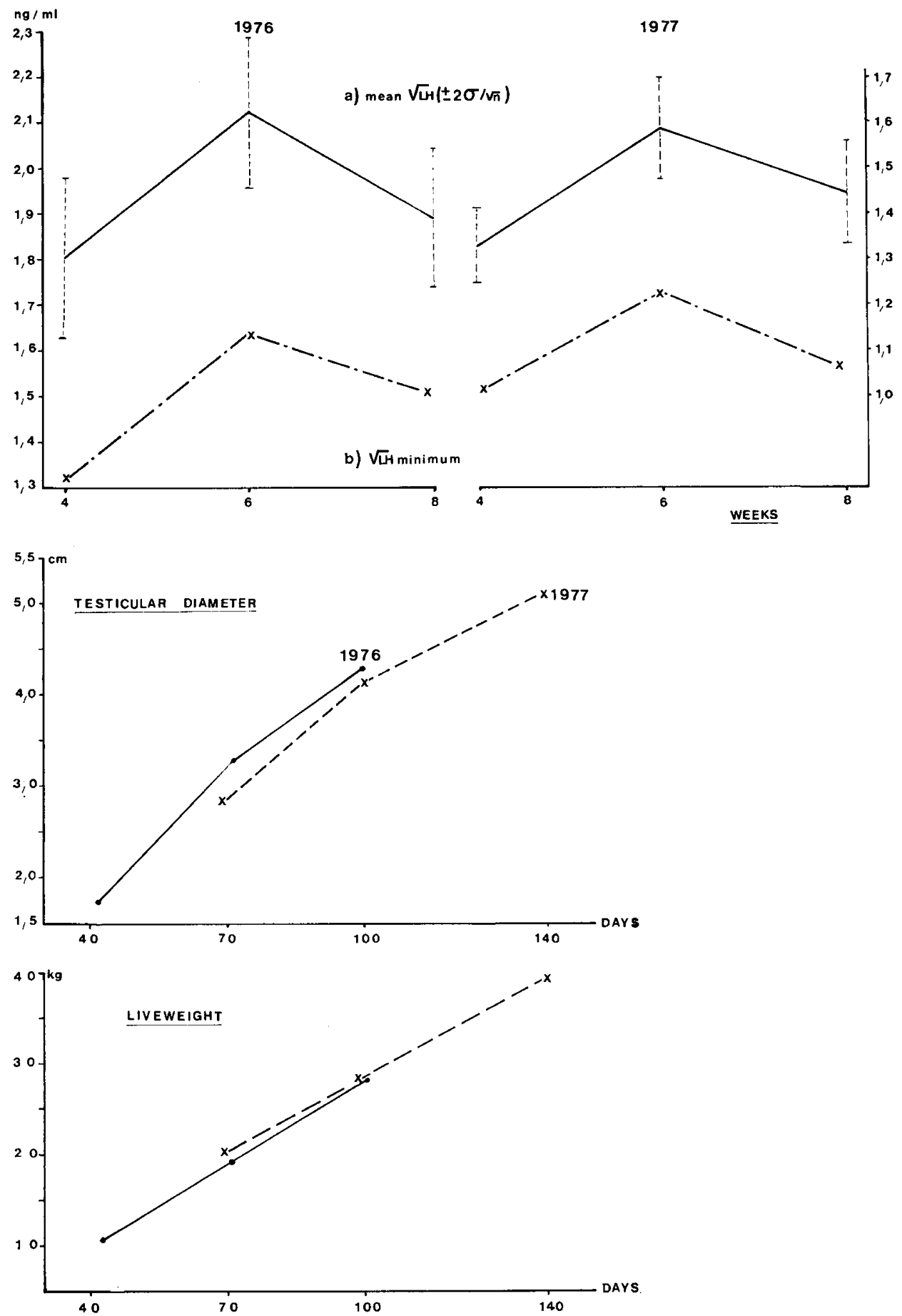

FIG. I. - Variation in $L H$ levels $(\sqrt{L H}$ and $\sqrt{L H}$ minimum) at 4,6 and 8 weeks, testicular diameters and liveweights of lambs, in 1976 and 1977

Variation des niveaux de $L H(\sqrt{L H}$ et $\sqrt{L H}$ minimum) $\grave{a} 4,6$ et 8 semaines, diamètres des testicules et poids vifs des agneaux en 1976 et 1977 
Age corrected testicular diameters were very significantly correlated with liveweight. Table 4 gives these correlations and the observed regressions.

TABLE 4

Relationships between liveweight $(x)$ and testicular diameter $(\mathrm{y})$

Relation entre le poids vif $(x)$ et le diamètre testiculaive $(\mathrm{y})$

\begin{tabular}{|c|c|c|c|c|c|}
\hline $\begin{array}{l}\text { Year } \\
(n)\end{array}$ & $\begin{array}{c}\text { Age } \\
\text { in days }\end{array}$ & $\begin{array}{c}\bar{x} \\
(\mathrm{~kg})\end{array}$ & $\begin{array}{c}\bar{y} \\
(\mathrm{~mm})\end{array}$ & $v_{u y}$ & $b y, x$ \\
\hline $\begin{array}{c}\mathbf{I 9 7 6} \\
(n=66)\end{array}$ & $\begin{array}{r}42 \\
70 \\
100\end{array}$ & $\begin{array}{l}\text { II }, 0 \\
\text { I } 9,7 \\
28,4\end{array}$ & $\begin{array}{l}17,4 \\
32,2 \\
42,7\end{array}$ & $\begin{array}{l}0,60 \\
0,66 \\
0,58\end{array}$ & $\begin{array}{l}0,92 \\
1,12 \\
0,65\end{array}$ \\
\hline$(n \stackrel{1977}{=} 93)$ & $\begin{array}{r}70 \\
100 \\
140\end{array}$ & $\begin{array}{l}20,6 \\
28,7 \\
39,0\end{array}$ & $\begin{array}{l}28,8 \\
4^{\mathrm{I}, 5} \\
5^{\mathrm{I}, 2}\end{array}$ & $\begin{array}{l}0,62 \\
0,47 \\
0,48\end{array}$ & $\begin{array}{l}0,85 \\
0,59 \\
0,45\end{array}$ \\
\hline
\end{tabular}

For CARR and IAND (1975), GABINA and FoLCH (r979), the correlation between 70 and r 20 days was of the order of $0,6-0,7$.

\section{Genetic differences}

The results of analysis of variance (table 5a) show that between-sire differences were significant at 6 weeks in 1976 and at both 4 and 8 weeks in 1977 for mean $\sqrt{\mathrm{LH}}$. However they were only very significant for mean $\sqrt{\mathrm{LH}}$ calculated on the 3 ages together in I977. The significances of the sire effects for the variable $\sqrt{\mathrm{LH}}$ minimum at the 3 ages were similar to those obtained with the variable mean $\sqrt{\mathrm{LH}}$.

With testicular measurements, between-sire differences were just significant for corrected testicular diameter at Ioo days in 1977 , but very significant for corrected testicular growth from 70-100 days in the same year (Table $5 b$ ).

On the basis of the results from the 2 years together ( 14 families), mean $\sqrt{\mathrm{LH}}$ measured from 4 to 8 weeks and testicular growth between 70 and roo days appear to be heritable characters. In particular, estimates of heritability $\left(h^{2}\right)$ calculated from the components of variance of table $3 a$, are higher than the estimates of BINDON et CH'ANG (I976) who observed an $h^{2}$ of less than o.Io on young lambs measured four times at 30 minute intervals.

\section{Correlations between variables (Table 6)}

All of the correlations between $\mathrm{LH}$ levels (mean $\sqrt{\mathrm{LH}}$ at 6,8 and 4 to 8 weeks) and testicular measurements (C.TD at roo days; C.TG from 42 to roo days or from 70 to Ioo days) were small and non-significant.

Increase in testicular diameter (corrected for liveweight) was not associated with weight at 70 days, but over-all it was significantly correlated to litter size: +0.36 for C.TG 42-Ioo days in 1976 and +0.24 for C.TG 70-Ioo days in I977. 
TABLE 5

Analysis of variance of differences between sires

Analyse de la variance des différences entre pères

a) Values of $F$ velative to measurememts of $L H$

Valeurs de $F$ relatives aux mesures de $L H$

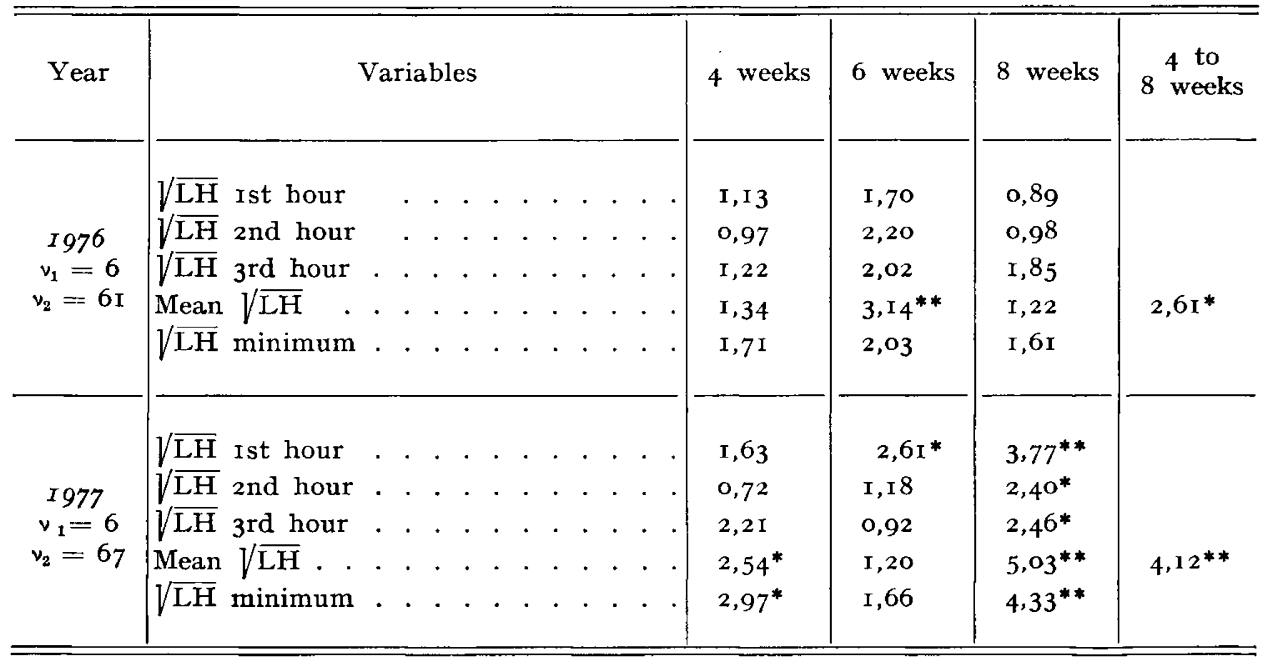

b) Values of $F$ relative to liveweight and to testicular measurements

Valeurs de $F$ relatives au poids vif et aux mesures testiculaires

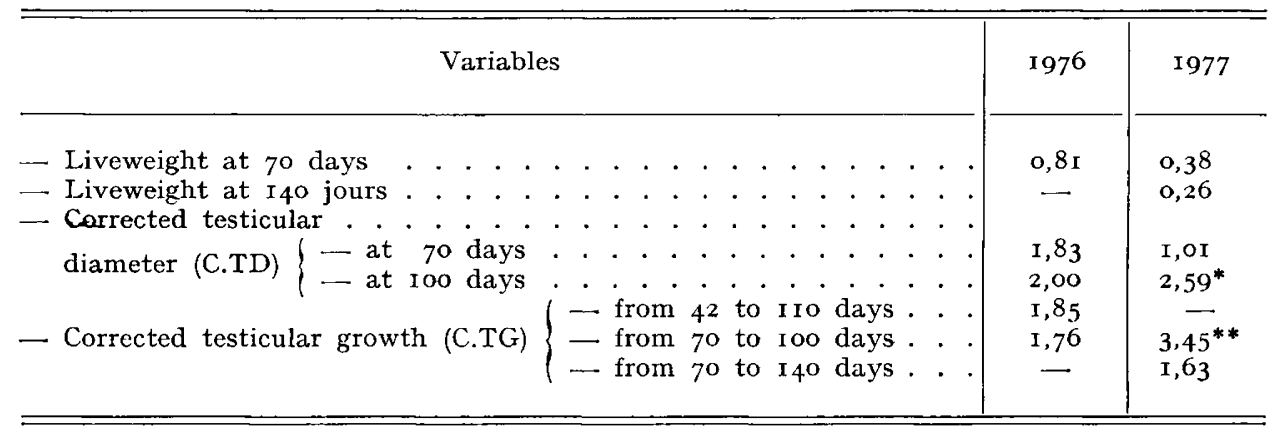

\section{II. - Correlations between half-sib families}

Because of the between-year differences in L.H. levels and the betweenfamily differences in ovulation rate each year $(2 . \mathrm{I} 2-2.30$ in $1976 ; 2,30-2.89$ in I 977), correlations were calculated separately for each series and mean correlations estimated from these (Table 7). Mean ovulation rates of half-sibs were practically independent of mean L.H. levels in the ram lambs. However there 


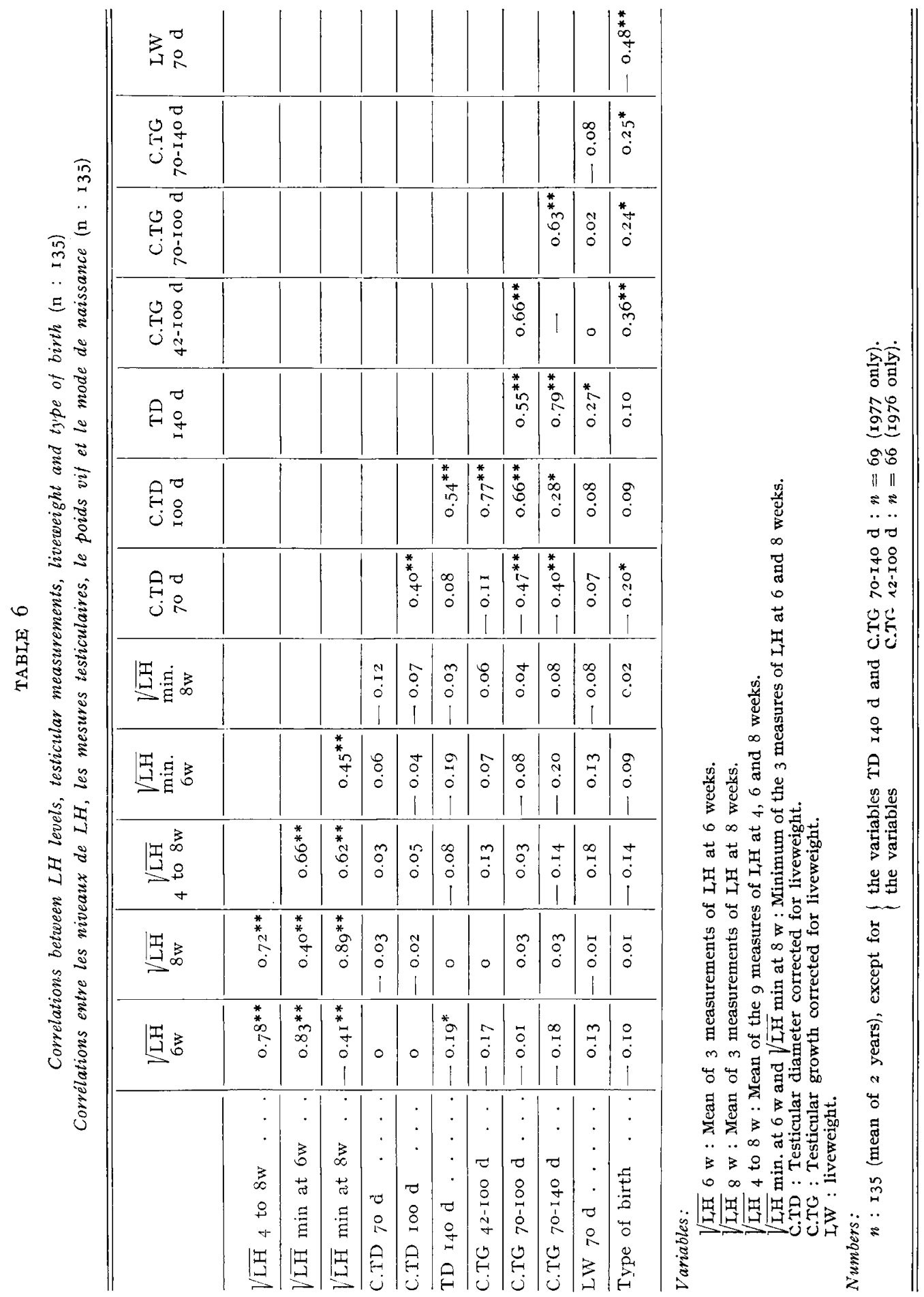


was a positive but non-significant correlation (0.43) between ovulation rate and corrected testicular growth from 70 to Ioo days.

\section{TABLE 7}

Correlations between means of each progeny: LH and testicular measurements for males, and ovulation rate of their paternal half-sisters $(1976+1977 ; n=14)$

Corrélations entre moyennes de chaque descendance: mesures de LH et mesures testiculaires pour les mâles et taux d'ovulation des demi-scurs de père

\begin{tabular}{|c|c|c|c|c|c|c|c|}
\hline & $\begin{array}{c}\sqrt{\mathrm{LH}} \\
\text { min. } \\
4 \text { to } 6 \mathrm{w}\end{array}$ & $\begin{array}{c}\sqrt{\sqrt{\mathrm{LH}}} \\
4 \text { to } 6 \mathrm{w}\end{array}$ & $\begin{array}{l}\text { C.TD } \\
7^{\circ} \mathrm{d}\end{array}$ & $\begin{array}{l}\text { C.TD } \\
\text { I oo d }\end{array}$ & $\begin{array}{c}\text { C.TG } \\
70-100 \quad d\end{array}$ & $\begin{array}{c}\text { TG } \\
70-100 \quad d\end{array}$ & $\begin{array}{r}\text { Type } \\
\text { of birth }\end{array}$ \\
\hline$\sqrt{\mathrm{LH}}_{4}$ to $6 \mathrm{w}$ & $0.97^{* *}$ & & & & & & \\
\hline C.TD $70 \mathrm{~d} \ldots$ & $\longrightarrow 0.39$ & $-0.4^{2}$ & & & & & \\
\hline C.TD I0o d & -0.02 & $0.0 \mathrm{r}$ & 0.27 & & & & \\
\hline C.TG $70-100 \mathrm{~d}$. & $0.3 \mathrm{I}$ & 0.39 & -0.52 & $0.72^{* *}$ & & & \\
\hline TG $70-100 \mathrm{~d}$ & 0.29 & 0.35 & -0.49 & $0.72^{* *}$ & $0.98 * *$ & & \\
\hline Type of birth & $-0.5^{8 *}$ & $-0.5^{8 *}$ & o & 0.04 & -0.04 & - 0.01 & \\
\hline Ovulation rate.. & 0.12 & 0.10 & 一 0.10 & $0.2 \mathrm{I}$ & 0.43 & $0.4^{\circ}$ & 0.15 \\
\hline
\end{tabular}

TABLE 8

Supplementary observations made on 14 Romanov males in 1978

Contrôles supplémentaives effectués sur I4 mâles Romanov en 1978

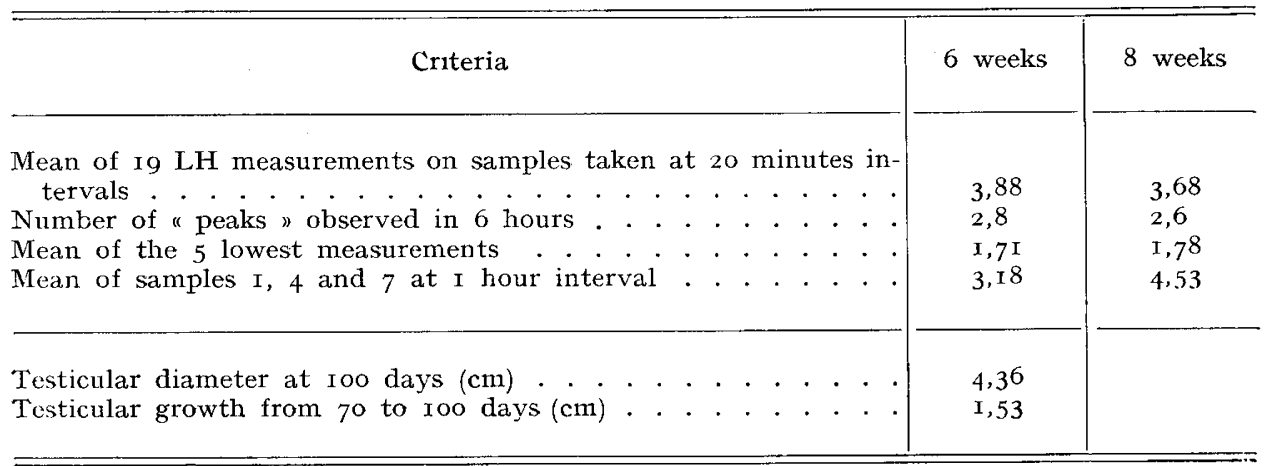




\section{Discussion}

\section{I. - Variability of L.H. measurements}

The results of this study confirm previous observations on the patterns of change of plasma L.H. levels (ThImonien et al., I972; BLANC et al., I975; CotTA et al., I975; LAND and CARR, I975; COUROT et al., I975; LEE et al., I976; ECHTERNKAMP and LASTER, I976; HANRAHAN et al., I977), although measurement periods and sampling methods were not the same. For example, blood samples were taken here at hourly intervals, while some other authors used intervals of $15,20,30$ or 90 minutes.

The repeatability of L.H. measures, between measurement times at the same age or between mean measurements at the 3 ages, differed from one year to the next. This was probably a result of the pulse-like release of $\mathrm{L}$. H. that the sampling was not able to cover with precision. While the correlation between mean L.H. level at 4 and 8 weeks was zero or only just significant (which corresponds to the results of HANRAHAN et al., I977; GABINA and FoLCH, I979), that observed between: 6 and 8 weeks was always highly significant. Overall, repeatability was no better for the variable $\sqrt{\mathrm{LH}}$ minimum, which eliminates in part the influence of discontinuous release of $\mathrm{LH}$, a result also observed by WESTHUYSEN and DIER KSE (I977).

With testicular growth from 6 to 20 weeks, the observed diameters for Romanov rams born in January-February were very close to those obtained with Finnsheep born in March-April (LAND and SALES, I977), although, here also, the measurement method was slightly different as scrotal skin thickness, which represents 5 to $7 \mathrm{~mm}$, was not deducted in this study.

\section{2. - Relationships between L.H. and testicular measurements}

Over the 2 years, the mean L.H. level of Romanov ram lambs was independent of their type of birth. This result agrees with the observation of HANRAHAN et al. (I977) but differs from those of Bindon (I973) who found a higher level of L.H. at 30 days among Merinos born in multiple births compared to those born as singles. In addition, like Gabina and FolCH (I979; Rasa Aragonesa lambs), we found no significant correlation between $\mathrm{L}$.H. level and testicular measurements, although a positive and significant correlation was reported by CARR and LAND (I975; I 4 lambs from 3 breeds), HANRAHAN and QUIR KE (I977; pooled correlation of 0.30 from 6 genetic groups having within-group correlations varying from 0.03 to 0.72 , cf. HANRAHAN, I976).

With more frequent blood samplings, it is possible to trace with precision the LH secretion profile. Thus, at the time of interpreting these results, it was considered that the absence of an observed correlation in this study may have been due in part to the relatively imprecise sampling routine. Consequently a supplementary control was established in 1978 with I4 Romanov ram lambs. Measurements were made at 6 and 8 weeks and, at each age, Ig blood samples were taken at 20 minute intervals from 8 a.m to 2 p.m. Two sets of testicular 
measurements were also made: testicular diameter at roo days and testicular growth between 70 and roo days. From the groups of measurements at 6 and 8 weeks, four criteria were defined for each ram lamb (table 8):

I) Mean of the I9 measurements.

2) Number of peaks observed during the 6 hours of sampling.

3) The mean of the lowest 5 values of each series of I9 as estimates of the base level of L.H.

4) Means of measurements $I, 4$ and 7 for comparison with the 3 measurements made in r 976 and r 977 (samples 4 and 7 were taken $r$ hour and 2 hours after the first).

Statistical analyses of these data show that the correlation between criteria I and 4 was relatively strong (0.77), that correlations between criteria I, 2 and 3 on the one hand and the 2 testicular measurements on the other, were practically zero. The observations are based on small numbers of lambs but they give no reason to detract from the results of the 2 preceeding years.

\section{3. - Correlations between sexes for the different parameters}

At the progeny level, the ovulation rates of young ewes are practically independent of measurements of L.H. in their half-brothers, although they had a positive but non-significant correlation with testicular growth between 70 and Ioo days. This last criterion is probably a better reflection of the group of hypophyseal factors controlling the male gonads, than the single hormone L.H., thus explaining the better correlation. This encouraging result confirms the indirect responses observed in ovulation rate or prolificacy following direct selection for testicular growth, and the reverse: LAND (I977, I979) and HANRAHAN and QUIRKE (I972) with sheep; IsLAm et al. (I976) with mice; Proud et al. (I976) and LEGAULT et al. (r979) with pigs. However it is necessary to continue this work with larger numbers of animals of different breeds and litter sizes in order to determine which method (individual selection or rapid family testing) and with what efficiency, measurements of testicular growth can assist in selection for fertility among sheep.

It is appropriate to emphasise that this work was carried out using a well defined character (ovulation rate of ewes at 9 montns) but with Romanov families that showed relatively little variation in this criterion. This could explain why no relationship was observed between male $\mathrm{LH}$ levels and ewe lamb ovulation rates.

Rę̧u pour publication en octobre 1979.

\section{Acknowledgements}

We thank R. Rouvier for aids to statistical analysis and W. A. PAtrie for the translation of the french manuscrit. 


\section{Résumé}

* Corrélations phénotypiques et génétiques entre critères endocriniens et mesures testiculaires chez les jeunes mâles Romanov et le taux d'ovulation à 8 mois de leurs demi-soeurs.

Cette étude a pour but d'estimer les relations entre le niveau de LH plasmatique des jeunes mâles de race Romanov à 4,6 et 8 semaines (à chaque âge, 3 prélèvements de sang à I heure d'intervalle), leur croissance testiculaire de 40 à I 40 jours et le taux d'ovulation de leurs demi-sœurs de père. Elle concerne 68 agneaux en 1976 et 74 agneaux en 1977 , issus au total de 14 pères.

Le niveau moyen de LH est maximum à 6 semaines et la corrélation entre les niveaux moyens de LH à 6 et 8 semaines est très significative. Les différences entre pères pour le niveau moyen de LH calculé sur l'ensemble des 3 âges et l'accroissement des testicules entre 70 et roo jours corrigé pour le poids vif ne sont très significatives qu'en I977.

Toutes les corrélations entre le niveau de $\mathrm{LH}$ et les mesures testiculaires sont non significatives. Le taux d'ovulation moyen des filles est indépendant du niveau moyen de $\mathrm{LH}$ de leurs demi-frères; il est en corrélation positive, mais non significative, avec l'accroissement testiculaire de 70 à roo jours (+ 0.43 avec $n=\mathrm{r}_{4}$ ).

La pulsatilité élevée de LH chez les agneaux de cet âge n'interfère pas sur les résultats obtenus comme le montre une série complémentaire de I 4 agneaux sur lesquels les prélèvements ont été effectués à 20 minutes d'intervalle pendant 6 heures et à l'âge de 6 et 8 semaines.

\section{References}

Bindon B. M., 1973. Genetic differences in plasma luteinizing hormone of the prepubertal lamb. J. Reprod. Fert., 32, 347-348.

Bindon B. M., PiPeR L. R., I976. Assessment of new and traditional techniques of selection for reproductive rate. In "Sheep Breeding". Ed. G. J. TomEs, D. E. Robertson and R. J. Lrghtfoor. West. Aust. Inst. Technol., 357-37I.

Bindon B. M., Ch'ang T. S., I976. Unpublished. Cited by Bindon and PiPer, I976.

Bindon B. M., Turner H. N., I974. Plasma LH of the prepubertal lamb: a possible early indicator of fecundity. J. Reprod. Fert., 39, 85-88.

Blanc M., Courot M., Pelletier J., Thimonier J., i975. Unpublished. Cited by Thimonier J., r975 : Étude de la puberté et de la saison sexuelle chez les races prolifiques et leurs croisements avec des races françaises. Journée de la Recherche ovine et caprine, I.N.R.A. et I.T.O.V.I.C., Paris, S.P.E.O.C., II, I 8-27.

CARR W. R., LAND R. B., 1975. Plasma luteinizing hormone levels and testis diameters of ram lambs of different breeds. J. Reprod. Fert., 42, 325-333.

Cotta Y., Terqui M., Pelletier J., Courot M., 1975. Plasma testosterone and LH in lambs from birth to puberty. C. R. Acad. Sci., Paris, D, 280, I473-I 476.

Courot M., de Reviers M. M., Pelletier J., I975. Variations in pituitary and blood LH during puberty in the male lamb. Relation to time of birth. Ann. Biol. Anim. Bioch. Biophys., 15, 509-5I6.

Echtern kamp S. E., LAster D. B., 1976. Plasma LH concentrations for prepubertal, postpubertal, anestrous and cyclic ewes of varying fecundity. J. Anim. Sci., 42, 444-447.

Gabina D., Folch J., 1979. Variabilidad Genetica del Crecimiento testicular y de la tasa de LH en el cordero de Raza Rasa Aragonesa. Symposium on sheep and cattle reproduction. Saragoza, may 1979.

HANRAhAN J. P., I976. Testis diameter in ram lambs and selection for litter size. In An Foras Taluntais Anim. Prod. Research. Report. p. I67 (abstr.).

Hanrahan J. P., Quirke J. F., 1977. Testis size and plasma luteinizing hormone as aids to selection for fecundity in sheep. Anim. Prod., 24, I48 (Abstr.).

Hanrahan J. P., Quirke J. F., Gosling J. P., I977. Genetic and non-genetic effects on plasma LH concentrations in lambs at 4 and 8 weeks of age. $J$. Reprod. Fert., 51, 343-349. 
Islam Mafizul A. B. M., Hill W. G., Land R. B., 1976. Ovulation rate of lines of mice selected for testis weight. Genet. Res., 27, 23-32.

LAND R. B., I972. Is mammalian fertility sex limited? J. Reprod. Fert., 31, 512.

LAND R. B., I973. The expression of female sex-limited characters in the male. Nature, 241, 208-209.

LAND R. B., 1977. Testis measurement as an aid to genetic selection for female reproduction. Report A.B.R.O., 1977, 23-29.

LAND R. B., 1979. Reproductive Physiology and genetic selection for reproductive traits. Symposium on sheep and cattle reproduction. Saragoza, may 1979.

LAND R. B., CARR W. R., I975. Testis growth and plasma LH concentration following hemicastration and its relation with female prolificacy in sheep. J. Reprod. Fert., 45, 495-501.

Land R. B., Sales D. I., I977. Mating behaviour and testis growth of Finnish Landrace, Tasmanian Merino and crossbred rams. Anim. Prod., 24, 83-9o.

Lee W. K., Cumming I. A., de Kretser D. M., Findlay J. K., Hudson B., Keogh E. J., i976. Regulation of gonadotrophin secretion in rams from birth to sexual maturity. I Plasma LH, FSH and testosterone levels. J. Reprod. Fert., 46, I-6.

Legault C., Gruand J., Oulion F., I979. Mise au point et intérêt génétique d'une méthode d'appréciation sur le vivant du poids des testicules chez le jeune verrat. Journées Rech. Porcine en France, 313-322.

Pelletier J., Kann G., Dolais J., Rosselin G., i968. Dosage radioimmunologique de l'hormone lutéinisante plasmatique chez le Mouton. Mise au point de la technique de dosage. $C . R$. Acad. Sci., Paris, Sér. D, 266, 2291-2294.

Proud D., Donovan D., Kinsey R., Cunningham P. J., Zimmerman D. R., I976. Testicular growth in boars as influenced by selection. J. Anim. Sci., 42, 1361-62 (Abstr.).

Thimonier J., Mauleon P., ig69. Variations saisonnières du comportement d'œstrus et des activités ovarienne et hypophysaire chez les ovins. Ann. Biol. Anim. Bioch. Biophys., 9, 233250.

Thimonier J., Pelletier J., Land R. B., I972. The concentration of plasma L.H in male and female lambs of high and low prolificacy breed types. J. Reprod. Fert., 31, 498-499.

Trounson A. O., Chamley W. A., Kennedy J. P., Tassel R., r974. Primordial follicle numbers in ovaries and level of LH and FSH in pituitaries and plasma of lambs selected for and against multiple births. Aust. J. Biol. Sci., 27, 293-299.

Westhuysen J. M., Dier KSE E., I977. The use of plasma luteinizing hormone as an indicator of prolificacy in sheep. S. Afr. J. Anim. Sci., 7, I57-159. 